\title{
Cloning and molecular characterization of a cDNA encoding a small GTPase from Hevea brasiliensis
}

\author{
H.L. Li ${ }^{1}$, D. Guo ${ }^{1}$, W.M. Tian² and S.Q. Peng ${ }^{1}$ \\ ${ }^{1}$ Key Laboratory of Biology and Genetic Resources of Tropical Crops, \\ Institute of Tropical Bioscience and Biotechnology, \\ Chinese Academy of Tropical Agricultural Sciences, \\ Ministry of Agriculture, Haikou, China \\ ${ }^{2}$ Key Laboratory of Biology and Genetic Resource of Rubber Tree, \\ Institute of Rubber, Chinese Academy of Tropical Agricultural Sciences, \\ Ministry of Agriculture, Danzhou, China \\ Corresponding author: S.Q. Peng \\ E-mail: shqpeng@163.com
}

Genet. Mol. Res. 12 (3): 3305-3313 (2013)

Received January 28, 2013

Accepted March 20, 2013

Published September 3, 2013

DOI http://dx.doi.org/10.4238/2013.September.3.7

\begin{abstract}
Small GTPases play a critical role in the regulation of a range of cellular processes including growth, differentiation, and intracellular transportation. The cDNA encoding a small GTPase, designated as HbGTPase1, was isolated from Hevea brasiliensis. HbGTPase1 was 882 bp long containing a 612-bp open reading frame encoding a putative protein of 203 amino acids, flanked by an 83-bp 5'-untranslated region (UTR) and a 187-bp 3'-UTR. The predicted molecular mass of HbGTPase1 is $22.62 \mathrm{kDa}$, with an isoelectric point of 5.06. The HbGTPase1 protein was predicted to possess the conserved functional regions of the small GTPase superfamily of proteins. Quantitative polymerase chain reaction analysis revealed that HbGTPasel was constitutively expressed in all tissues tested. HbGTPase1 transcripts accumulated at relatively low levels in the flower, latex, and leaves, while HbGTPasel transcripts accumulated at
\end{abstract}


relatively high levels in bark. Transcription of HbGTPase1 in the latex was induced by jasmonate.

Key words: GTPase; Hevea brasiliensis; Latex; Jasmonate

\section{INTRODUCTION}

GTPases are grouped into 2 major classes, the small GTPases and the heterotrimeric G proteins (Assmann, 2002). Small GTPases, proteins with molecular masses between 21 and $30 \mathrm{kDa}$, are monomeric guanine nucleotide-binding proteins related to a subunit of heterotrimeric G proteins (Yang, 2002). They are universal molecular switches, regulating several cellular processes such as vesicle trafficking, cytoskeletal dynamics, cell polarity, and gene expression, by cycling between an "activated" state when bound to GTP and a GDP-bound inactive state (Takai et al., 2001; Vernoud et al., 2003). Upon stimulation by an upstream signal, the GTP-bound active form interacts with specific downstream effector proteins, which leads to the regulation of cellular responses and developmental processes that are highly conserved throughout eukaryotes (Molendijk et al., 2004; Wu et al., 2011). The small GTPase superfamily is divided into at least 5 families, including Ras, Rho, Arf, Ran, and Rab, although there are no Ras GTPases in plants (Vernoud et al., 2003). Members of this class of proteins are among the largest families of signaling proteins in eukaryotic cells (Yang, 2002; Vernoud et al., 2003).

Hevea brasiliensis Muell-Arg is the only cultivated species, and the main source, of natural rubber (Gouvêa et al., 2010). The economic importance of natural rubber has prompted investigations regarding the biochemistry and cell biology of latex biogenesis (Kush, 1994), but the physiological processes of latex remain mysterious (Ko et al., 2003). Latex constitutes the cytoplasmic component of the laticifers and latex vessels in H. brasiliensis. Although laticifers are the major location for rubber biosynthesis, the molecular mechanisms of this pathway and the regulation of natural rubber production in $\mathrm{H}$. brasiliensis are not well known (Chow et al., 2007). In this study, we report results of the cloning and characterization of the small GTPase gene from H. brasiliensis (GenBank No. JQ943654). To our knowledge, this is the first small GTPase gene cloned and characterized from $H$. brasiliensis. The expression profiles of HbGTPase 1 in $H$. brasiliensis were also investigated. The present study contributes to an understanding of the molecular characterization of the small GTPase and its possible function in the rubber tree.

\section{MATERIAL AND METHODS}

\section{Plant material}

Virgin rubber trees (H. brasiliensis) of clone RY-7-33-97 were planted in 2007 in the Experimental Farm of the Chinese Academy of Tropical Agriculture Science. The selected trees with a girth of $50-55 \mathrm{~cm}$ were treated with $0.2 \%$ ethephon and $0.1 \%$ jasmonic acid (JA), following the Hao method (Hao and $\mathrm{Wu}, 2000$ ). For latex RNA extraction, rubber trees were tapped using a tapping knife. The first few drops of latex, which contained mostly debris from the plant, were discarded. The latex was allowed to drop directly into liquid nitrogen in an ice kettle. The frozen latex powder was either stored at $-70^{\circ} \mathrm{C}$ or used immediately. Rubber tree 
leaves, flowers, and buds were washed with double-distilled $\mathrm{H}_{2} \mathrm{O}$ to remove latex and immediately frozen in liquid nitrogen. Frozen leaves, flowers, and bark were stored at $-70^{\circ} \mathrm{C}$ or immediately used.

\section{Isolation of RNA}

Total RNA was extracted according to methods described in Tang et al., 2007. The quality and concentration of the extracted RNA were checked by agarose gel electrophoresis and measured by spectrophotometry (DU-70, Beckman, USA).

\section{3'-Rapid amplification of cDNA ends (RACE) of HbGTPase1}

3'-Ready cDNA was synthesized by reversely transcribing $1 \mu \mathrm{g}$ total RNA with 3'CDS primer A (provided in the kit). 3'-RACE primer 3P1 (5'-AGCTTCTGGTTGGGAACAA GTGTGATC-3') was designed and synthesized based on the expressed sequence tag (EST) from the latex cDNA library. 3'-RACE was carried out in a total volume of $25 \mathrm{~mL}$, containing $1 \mu \mathrm{L} 3^{\prime}$-ready cDNA, and run for 35 cycles of amplification $\left(94^{\circ} \mathrm{C}\right.$ for $15 \mathrm{~s}, 68^{\circ} \mathrm{C}$ for $30 \mathrm{~s}$, and $72^{\circ} \mathrm{C}$ for $1 \mathrm{~min}$ ). The product was purified and cloned into a pGEM-T easy vector (Promega), followed by sequencing.

\section{5'-RACE of HbGTPase1}

An aliquot of $1 \mu \mathrm{g}$ total RNA was reverse transcribed with 5'-CDS primer A and SMART II A oligonucleotides (provided in the kit) to obtain the 5'-ready cDNA, using the SMART $^{\mathrm{TM}}$ RACE cDNA Amplification Kit (Clontech, Palo Alto, CA, USA). 5'-RACE primer 5P1 (5'-AATGCCATGTGCTCCACGGTAATAGCT-3') and nested primer 5P2 (5'-CGTTCTTGTCCTGCAGTATCCCAAATT-3') were designed and synthesized based on the EST from the latex cDNA library. Primary 5'-RACE polymerase chain reaction (PCR) was performed with the 5P1 and UPM primers (provided in the kit) in a total volume of $25 \mu \mathrm{L}$ containing cDNA, and was denatured at $94^{\circ} \mathrm{C}$ for $3 \mathrm{~min}$, followed by 32 cycles of amplification ( $5 \mathrm{~s}$ denaturation at $94^{\circ} \mathrm{C}, 10 \mathrm{~s}$ annealing at $68^{\circ} \mathrm{C}$, and a 1 -min extension at $72^{\circ} \mathrm{C}$ ). The product of the primary PCR was diluted 50-fold, and was used as a template for nested PCR performed with the primers 5P2 and NUP (provided in the kit). The product was purified and cloned into the pGEM-T easy vector (Promega) and sequenced.

\section{Cloning of the full-length cDNA of HbGTPase1}

After alignment and assembly of the internal conserved sequence and the 3'- and 5'RACE products, the full-length cDNA sequence of the HbGTPasel gene was deduced and subsequently obtained by PCR. The open reading frame (ORF) of HbGTPasel was amplified by reverse transcription PCR (RT-PCR), using the primers HbGTPase1F (5'-AAGAGGAGA ATCAGAGC-3') and HbGTPase1R (5'-TTTACAGCTCTCTATGCGGCAAC-3') with the TAKARA RNA PCR kit. An aliquot of $1 \mu \mathrm{g}$ total RNA was reversely transcribed according to manufacturer protocols, and $2 \mu \mathrm{L}$ cDNA was used in PCR in a total volume of $50 \mu \mathrm{L}$ under the following program: $94^{\circ} \mathrm{C}$ for $2 \mathrm{~min}$, followed by 32 cycles of amplification $\left(94^{\circ} \mathrm{C}\right.$ for $15 \mathrm{~s}$, 
$58^{\circ} \mathrm{C}$ for $30 \mathrm{~s}$, and $72^{\circ} \mathrm{C}$ for $2 \mathrm{~min}$ ). The PCR product was purified and cloned into the pGEM$\mathrm{T}$ easy vector (Promega) followed by sequencing.

\section{Multiple alignments and bioinformatic analyses}

The nucleotide sequence, deduced amino acid sequence, and ORF encoded by HbGTPase 1 were analyzed. The sequence comparison was conducted by a database search using the BLAST program (http://www.ncbi.nlm.nih.gov). Multiple alignments were carried out using the ClustalX software, version 1.81 (Thompson et al., 1997).

\section{Analysis of HbGTPase1 expression}

The quantitative PCR (qPCR) primer P1 (5'-CAGAAGTCTGGATGCTGCTCTTCT-3') and primer P2 (5'-TGGTTTAAGGTGGGAATAGTCTCT-3') were designed and synthesized based on the HbGTPasel sequence. The qPCR was performed using the fluorescent dye SYBRGreen (Takara, Dalian, China) and the BIO-RAD CFX96 Real-Time PCR system (Bio-Rad, USA). The reactions were carried out as follows: $30 \mathrm{~s}$ at $95^{\circ} \mathrm{C}$ for denaturation, $5 \mathrm{~s}$ at $94^{\circ} \mathrm{C}, 20$ $\mathrm{s}$ at $60^{\circ} \mathrm{C}$, and $20 \mathrm{~s}$ at $72^{\circ} \mathrm{C}$ for amplification. Three biological replicates were carried out and triplicate quantitative assays for each replicate were performed. A rubber tree Actin gene was amplified as an internal control. The relative abundance of transcripts was calculated according to the Bio-Rad CFX Manager (Version 1.5.534) of BIO-RAD CFX96.

\section{RESULTS}

\section{Cloning and characterization of HbGTPase1}

The EST from the latex cDNA library, which showed similarity to other plant small GTPase genes based on a BLASTX search, was obtained in a previous study (Liang et al., 2009). The BLASTX search revealed that the EST contained part of the ORF of the small GTPase gene. Based on the sequence of the fragment, 3'- and 5'-RACE primers were designed to amplify unknown 3'- and 5'-end sequences of HbGTPasel cDNAs, using 3'- and 5'-RACE strategies. The amplified products of the 3'- and 5'-end cDNA fragments were 289 and $453 \mathrm{bp}$ in length, respectively. By alignment and assembly of these 2 sequences with the EST, the full-length cDNA sequence of HbGTPasel was deduced, amplified by PCR, and ultimately confirmed by sequencing. The full-length cDNA was $882 \mathrm{bp}$ in length, and it contained a 612-bp ORF, with a 3'-untranslated region (UTR) of $187 \mathrm{bp}$ downstream of the stop codon, and a 5'-UTR of $83 \mathrm{bp}$ upstream of the start codon (Figure 1).

The deduced HbGTPase 1 protein consisted of 203-amino acid residues with a calculated molecular weight of $22.62 \mathrm{kDa}$ and an isoelectric point of 5.06. The HbGTPase 1 protein contains the conserved functional regions and domains of the small GTPase superfamily of proteins (Figure 1), which are shared by the majority of GTPases (Bourne et al., 1991; Dombrowski et al., 2008). Domains G1-G3 are involved in binding magnesium and GTP phosphate residues and domains G4 and G5 are involved in binding the guanine moiety (Bourne et al., 1991). 


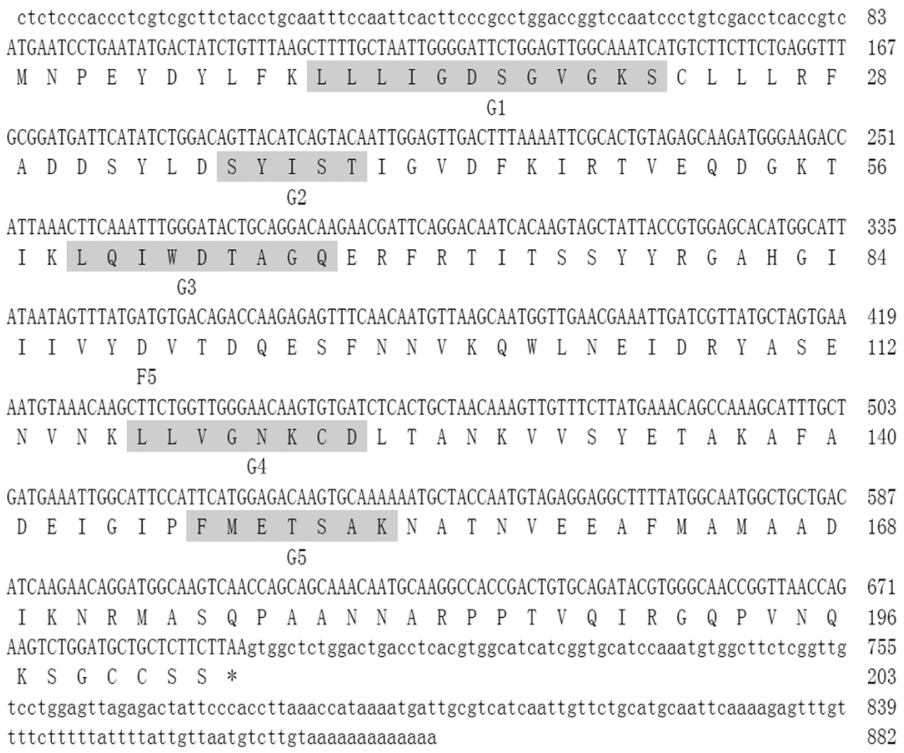

Figure 1. Nucleotide and deduced amino acid sequences of HbGTPase1. Numbers corresponding to the nucleotide and amino acid sequence are indicated on the left and right, respectively. Conserved domains of the GTPase superfamily of proteins are highlighted in gray, labeled G1-G5. Domains G1-G3 are involved in binding magnesium and GTP phosphate residues and G4 and G5 are involved in binding the guanine moiety.

The phylogenetic analysis of HbGTPase 1 was constructed using closely related small GTPase members from Arabidopsis thaliana. The tree revealed that the HbGTPase1 protein is located on a branch with the $A$. thaliana Rab GTPase (Figure 2).

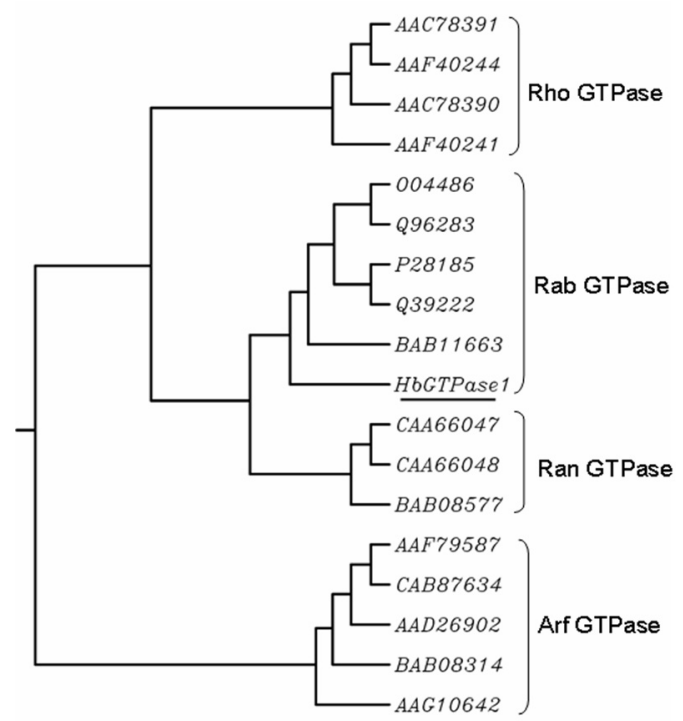

Figure 2. Phylogenetic tree of HbGTPase1 and small GTPase members from Arabidopsis thaliana with indicated GenBank accession numbers. 


\section{Differential expression of HbGTPase1 in different tissues}

Accumulation of HbGTPasel transcripts in different tissues was examined using qPCR analysis. The results showed that HbGTPasel was constitutively expressed in all tissues tested. HbGTPasel transcripts accumulated at relatively low levels in flowers, latex, and leaves, while HbGTPasel transcripts accumulated at relatively high levels in bark (Figure 3).

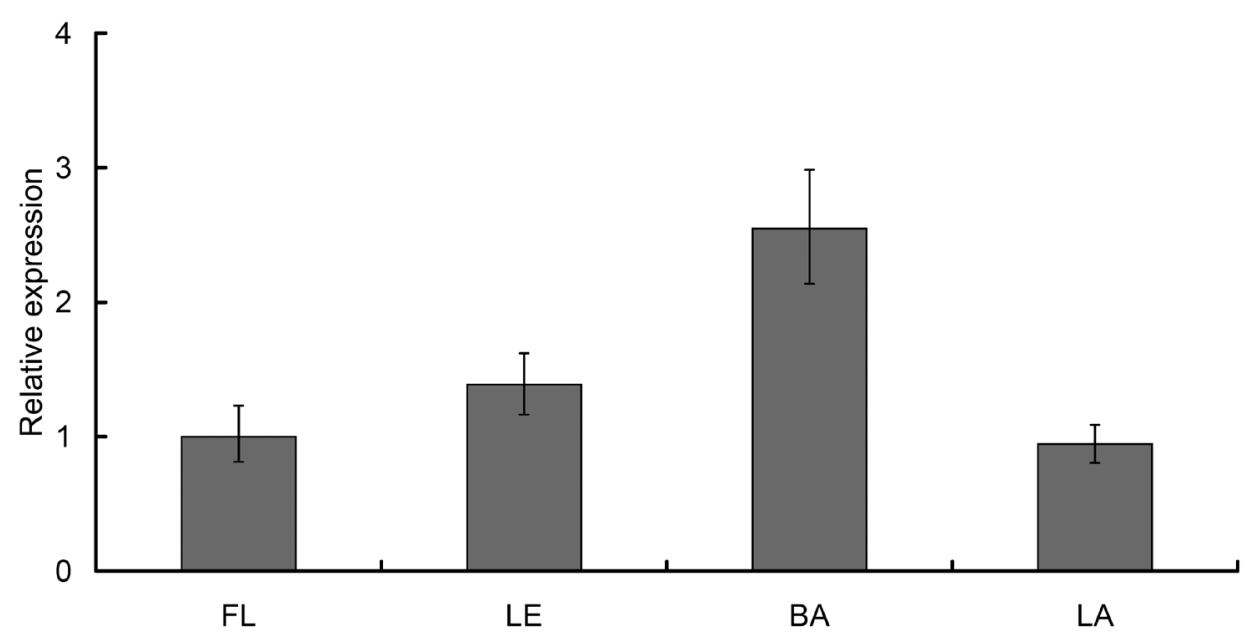

Figure 3. Transcription pattern analysis of HbGTPase1. The qPCR was performed on RNA derived from various tissues from the rubber tree. Actin was amplified for normalization. $\mathrm{FL}=$ flowers; $\mathrm{LE}=$ leaves; $\mathrm{BA}=$ bark; $\mathrm{LA}=$ latex.

\section{Effects of ethephon and JA on HbGTPase1 expression in latex}

Ethephon, a stimulant of latex production in the rubber tree, has been widely used in commercial latex production practices (Zhu and Zhang, 2009). Furthermore, biosynthesis of natural rubber is enhanced in rubber trees by the endogenous accumulation and the exogenous application of JA (Yu et al., 2007). Therefore, we tested whether ethephon and JA application had any effect on HbGTPasel expression in laticifer cells. The qRT-PCR analysis demonstrated that the HbGTPasel transcript was induced by JA, while ethephon was not effective in inducing HbGTPase1 expression (Figure 4).

\section{DISCUSSION}

Small GTPases regulate diverse processes in eukaryotic cells such as cell proliferation, cytoskeletal organization, signal transduction, and intracellular membrane trafficking (Yang, 2002; Vernoud et al., 2003; Gu et al., 2004; Nielsen et al., 2008). A phylogenetic analysis revealed that small GTPases are classified into 4 groups in plants: Rab, Rho, Arf, and Ran (Vernoud et al., 2003). In this study, we present results on the cloning and characterization of the gene encoding a small GTPase from the rubber tree. The HbGTPase1 protein contained highly conserved motifs typical of the GTPase superfamily. When the HbGTPase1 protein was compared to representative members of Arabidopsis small GTP binding proteins, 

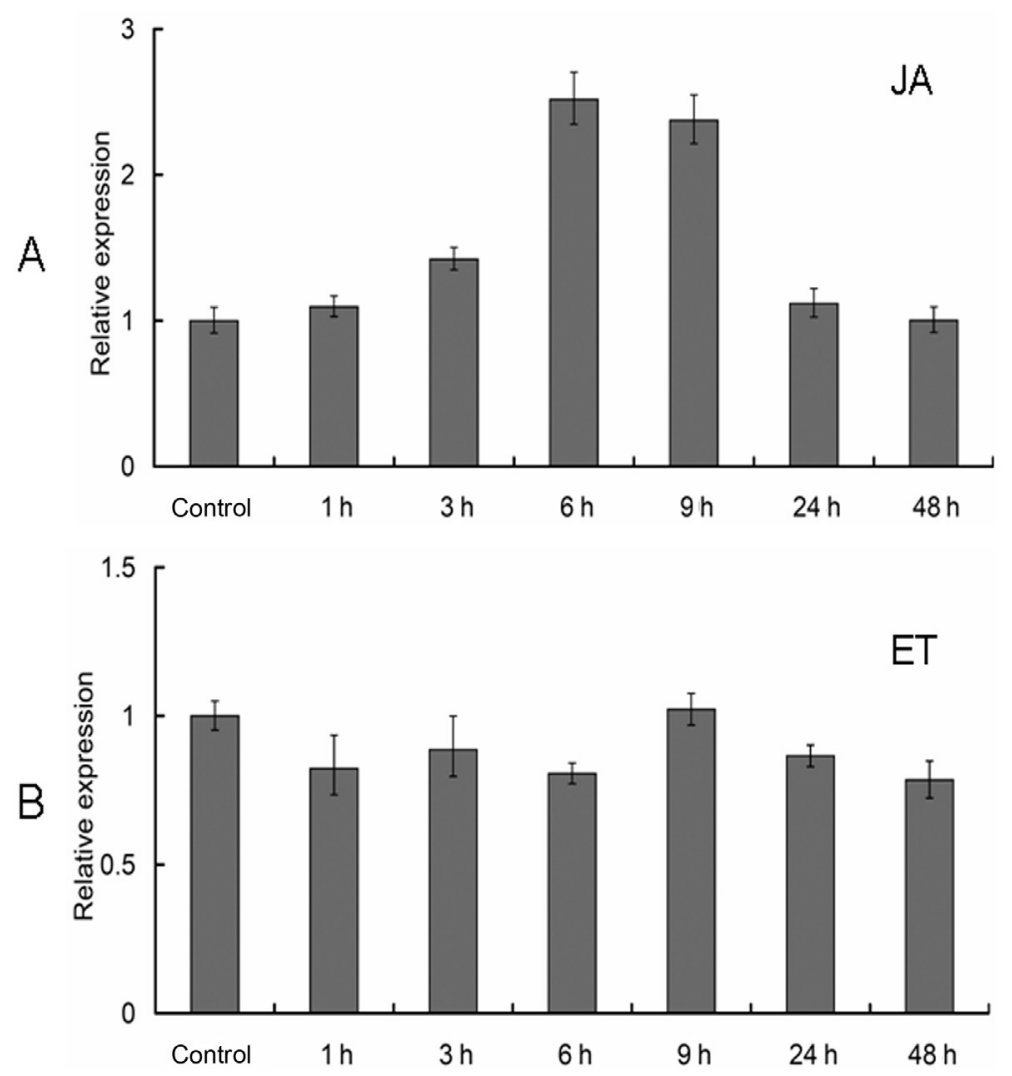

Figure 4. Effects of hormones on the expression of HbGTPasel in the latex. RNA extracted from the extruded latex of rubber trees treated with ethephon or JA for 0 (control), 1, 3, 6, 9, 24, or $48 \mathrm{~h}$ were subjected to qRCR assay; Actin was used as a control. A. The HbGTPasel transcript in latex is induced by jasmonic acid (JA) treatment. B. The HbGTPasel transcript is not induced following ethephon treatment (ET).

it was grouped with the Rab subfamily. The Rab subfamily of GTPases has been shown to be involved with stress tolerance. In jojoba and ice plants, a Rab5 GTPase family member was upregulated in response to salt stress (Bolte et al., 2000; Mizrahi-Aviv et al., 2002). The OsRab7 gene was differentially regulated in response to cold, salt, dehydration, and abscisic acid in rice (Nahm et al., 2003). The smGTP gene, which is related to the Rab2 gene family of GTPases, was strongly induced by salt stress in root, crown, and leaf tissues in Lolium temulentum (Dombrowski et al., 2008). In the present study, qRT-PCR analysis showed that the HbGTPasel transcript was upregulated in response to JA.

JA is a key signal in the elicitation of secondary metabolism, an important defense response. Elicitors of the processes of secondary metabolism induce JA biosynthesis as an early response, and JA subsequently induces expression of genes that code for the synthesis of enzymes involved in the biosynthetic processes involved in secondary metabolism (Menke et al., 1999; van der Fits and Memelink, 2000). JA can induce laticifer differentiation and may regulate rubber biosynthesis (Hao and Wu, 2000; Wu et al., 2002; Yu et al., 2007; Peng et al., 
2009). It will be of great interest to elucidate whether or not rubber biosynthesis is regulated by small GTPases. Cloning more small GTPase genes should provide further understanding about the relationship between JA signal transduction, small GTPases, and the biosynthesis and regulation of natural rubber in the rubber tree.

\section{ACKNOWLEDGMENTS}

Research supported by the National Natural Science Foundation of China (\#31170634) and Hainan Sciences and Technology Major Projects (\#ZDZX2013023-1).

\section{REFERENCES}

Assmann SM (2002). Heterotrimeric and unconventional GTP binding proteins in plant cell signaling. Plant Cell 14 Suppl: S355-S373.

Bolte S, Schiene K and Dietz KJ (2000). Characterization of a small GTP-binding protein of the rab 5 family in Mesembryanthemum crystallinum with increased level of expression during early salt stress. Plant Mol. Biol. 42: 923-936.

Bourne HR, Sanders DA and McCormick F (1991). The GTPase superfamily: conserved structure and molecular mechanism. Nature 349: 117-127.

Chow KS, Wan KL, Isa MN, Bahari A, et al. (2007). Insights into rubber biosynthesis from transcriptome analysis of Hevea brasiliensis latex. J. Exp. Bot. 58: 2429-2440.

Dombrowski JE, Baldwin JC and Martin RC (2008). Cloning and characterization of a salt stress-inducible small GTPase gene from the model grass species Lolium temulentum. J. Plant Physiol. 165: 651-661.

Gouvêa LR, Rubiano LB, Chioratto AF, Zucchi MI, et al. (2010). Genetic divergence of rubber tree estimated by multivariate techniques and microsatellite markers. Genet. Mol. Biol. 33: 308-318.

Gu Y, Wang Z and Yang Z (2004). ROP/RAC GTPase: an old new master regulator for plant signaling. Curr. Opin. Plant Biol. 7: 527-536.

Hao BZ and $\mathrm{Wu} J \mathrm{~J}$ (2000). Laticifer differentiation in Hevea brasileinsis: induction by exogenous jasmonic acid and linolenic acid. Ann. Bot. 85: 37-43.

Ko JH, Chow KS and Han KH (2003). Transcriptome analysis reveals novel features of the molecular events occurring in the laticifers of Hevea brasiliensis (para rubber tree). Plant Mol. Biol. 53: 479-492.

Kush A (1994). Isoprenoid biosynthesis: the Hevea factory. Plant Physiol. Biochem. 32: 761-767.

Liang XL, Li HL and Peng SQ (2009). Cloning and expression of HbTCTP from Hevea brasiliensis. Mol. Plant Breed. 7: 194-198.

Menke FL, Champion A, Kijne JW and Memelink J (1999). A novel jasmonate- and elicitor-responsive element in the periwinkle secondary metabolite biosynthetic gene Str interacts with a jasmonate- and elicitor-inducible AP2-domain transcription factor, ORCA2. EMBO J. 18: 4455-4463.

Mizrahi-Aviv E, Mills D, Benzioni A and Bar-Zvi D (2002). Cloning and molecular characterization of the salt-regulated jojoba ScRab cDNA encoding a small GTP-binding protein. DNA Seq. 13: 295-300.

Molendijk AJ, Ruperti B and Palme K (2004). Small GTPases in vesicle trafficking. Curr. Opin. Plant Biol. 7: 694-700.

Nahm MY, Kim SW, Yun D, Lee SY, et al. (2003). Molecular and biochemical analyses of OsRab7, a rice Rab7 homolog. Plant Cell Physiol. 44: 1341-1349.

Nielsen E, Cheung AY and Ueda T (2008). The regulatory RAB and ARF GTPases for vesicular trafficking. Plant Physiol. 147: 1516-1526.

Peng SQ, Xu J, Li HL and Tian WM (2009). Cloning and molecular characterization of HbCOII from Hevea brasiliensis. Biosci. Biotechnol. Biochem. 73: 665-670.

Takai Y, Sasaki T and Matozaki T (2001). Small GTP-binding proteins. Physiol. Rev. 81: 153-208.

Tang C, Qi J, Li H, Zhang C, et al. (2007). A convenient and efficient protocol for isolating high-quality RNA from latex of Hevea brasiliensis (para rubber tree). J. Biochem. Biophys. Methods 70: 749-754.

Thompson JD, Gibson TJ, Plewniak F, Jeanmougin F, et al. (1997). The CLUSTAL_X windows interface: flexible strategies for multiple sequence alignment aided by quality analysis tools. Nucleic Acids Res. 25: 4876-4882.

van der Fits L and Memelink J (2000). ORCA3, a jasmonateresponsive transriptional regulator of plant primary and secondary metabolism. Science 289: 295-297. 
Vernoud V, Horton AC, Yang Z and Nielsen E (2003). Analysis of the small GTPase gene superfamily of Arabidopsis. Plant Physiol. 131: 1191-1208.

Wu JL, Hao BZ and Tan HY (2002). Wound-induced differentiation in Hevea brasiliensis shoots mediated by jasmonic acid. J. Rubb. Res. 5: 53-63.

Wu HM, Hazak O, Cheung AY and Yalovsky S (2011). RAC/ROP GTPases and auxin signaling. Plant Cell 23: $1208-1218$.

Yang Z (2002). Small GTPases: versatile signaling switches in plants. Plant Cell 14 Suppl: S375-S388.

Yu JH, Yang SG, Huang MJ and Tian WM (2007). Effects of season, exploitation and exogenous jasmonic acid on the laticifer differentiation in mature rubber tree. Chin. J. Trop. Crops 28: 1-5.

Zhu J and Zhang Z (2009). Ethylene stimulation of latex production in Hevea brasiliensis. Plant Signal. Behav. 4: 1072-1074. 